University of Nebraska - Lincoln

DigitalCommons@University of Nebraska - Lincoln

$11-2008$

\title{
Jointed Goatgrass Management with Imazamox-Resistant Cultivars in a Winter Wheat-Fallow Rotation
}

Andrew R. Kniss

University of Wyoming, akniss@uwyo.edu

Drew J. Lyon

University of Nebraska-Lincoln, drew.lyon@wsu.edu

Stephen D. Miller

University of Wyoming

Follow this and additional works at: https://digitalcommons.unl.edu/panhandleresext

Part of the Agriculture Commons

Kniss, Andrew R.; Lyon, Drew J.; and Miller, Stephen D., "Jointed Goatgrass Management with ImazamoxResistant Cultivars in a Winter Wheat-Fallow Rotation" (2008). Panhandle Research and Extension Center. 1.

https://digitalcommons.unl.edu/panhandleresext/1

This Article is brought to you for free and open access by the Agricultural Research Division of IANR at DigitalCommons@University of Nebraska - Lincoln. It has been accepted for inclusion in Panhandle Research and Extension Center by an authorized administrator of DigitalCommons@University of Nebraska - Lincoln. 


\title{
Agricultural Research Division of IANR Panhandle Research and Extension Center - Press Releases
}

\section{Jointed Goatgrass Management with Imazamox-Resistant Cultivars in a Winter Wheat-Fallow Rotation}

\author{
Andrew R. Kniss* \\ Drew J. Lyon ${ }^{\dagger}$
}

Stephen D. Miller ${ }^{\ddagger}$

*University of Nebraska-Lincoln

${ }^{\dagger}$ University of Nebraska-Lincoln, dlyon1@unl.edu

$\ddagger$ University of Nebraska-Lincoln

This paper is posted at DigitalCommons@University of Nebraska - Lincoln.

http://digitalcommons.unl.edu/panpressrel/10 


\title{
Jointed Goatgrass Management with Imazamox-Resistant Cultivars in a Winter Wheat-Fallow Rotation
}

\author{
Andrew R. Kniss,^ Drew J. Lyon, and Stephen D. Miller
}

\begin{abstract}
Jointed goatgrass (Aegilops cylindrica Host) is an economically important weed in winter wheat (Triticum aestivum L.)-fallow production regions of the United States. Few options exist for management of jointed goatgrass in winter wheat due to the close genetic relationship between the two species. This research evaluated use of imazamox herbicide (2-[(RS)-4-isopropyl-4methyl-5-oxo-2-imidazolin-2-yl]-5-methoxymethylnicotinic acid) in an imazamox-resistant (IR) winter wheat-fallow rotation over $6 \mathrm{yr}$ when grown continuously or in rotation with a conventional winter wheat cultivar. The objectives of this study were to compare use patterns of IR technology in winter wheat with respect to jointed goatgrass density and wheat grain contamination over three crop years in a winter wheat-fallow system and to monitor jointed goatgrass and jointed goatgrass $\times$ wheat hybrid populations for resistance to imazamox. The IR treatment resulted in reduced jointed goatgrass density compared to conventional treatments in 5 out of 6 yr. Reductions in jointed goatgrass tiller density resulting from use of imazamox in IR winter wheat were evident in a subsequent crop year at each of two experimental sites. No IR jointed goatgrass plants nor viable jointed goatgrass $x$ wheat hybrid plants were found. In a winter wheat-fallow rotation, IR technology can effectively manage jointed goatgrass populations and reduce jointed goatgrass contamination of grain. Use of the technology every other crop year, or two out of every three crop years, will provide management benefits in subsequent years.
\end{abstract}

A.R. Kniss, Dep. of Plant Sciences, and S.D. Miller, Agricultural Experiment Station, Univ. of Wyoming, Laramie, WY 82071; D.J. Lyon, Dep. of Agronomy and Horticulture, Univ. of Nebraska Panhandle Research and Extension Center, Scottsbluff, NE 69361. Received 21 Dec. 2007. *Corresponding author (akniss@uwyo.edu).

Abbreviations: ALS, acetolactose synthase; IR, imazamox-resistant; RCBD, randomized complete block design; STD, standard.

$\int_{\text {pro }}$ OINTED GOATgrass (Aegilops cylindrica Host) is an economically important weed in winter wheat (Triticum aestivum L.)-fallow production regions of the United States. Jointed goatgrass competes with winter wheat and can reduce yield even if emerging up to $100 \mathrm{~d}$ after the wheat crop (Anderson, 1993b). Jointed goatgrass tends to be more competitive than winter wheat when stressful growing conditions are present (Fleming et al., 1988). In addition to direct yield loss from competition, jointed goatgrass spikelets can contaminate winter wheat grain, resulting in economic discounts at the elevator. It was estimated that between 1990 and 1992, nearly $30 \%$ of the winter wheat delivered to elevators in western Nebraska was contaminated with jointed goatgrass spikelets (Lyon et al., 1994). Jointed goatgrass has been designated as a noxious weed in several western U.S. states, making the sale of jointed goatgrass-infested grain illegal (Donald and Ogg, 1991).

Management of jointed goatgrass in winter wheat is complicated by close genetic and phenotypic similarities between the two species. Growth patterns are similar between the two species (Anderson, 1993b; Ball et al., 1995; Dotray and Young, 1993), making selective mechanical or chemical control in-crop difficult. Jointed goatgrass management has historically focused on cultural control practices such as extended rotations (Lyon and

Published in Crop Sci. 48:2414-2420 (2008).

doi: 10.2135/cropsci2007.12.0698

(C) Crop Science Society of America

677 S. Segoe Rd., Madison, WI 53711 USA

All rights reserved. No part of this periodical may be reproduced or transmitted in any form or by any means, electronic or mechanical, including photocopying, recording, or any information storage and retrieval system, without permission in writing from the publisher. Permission for printing and for reprinting the material contained herein has been obtained by the publisher. 
Baltensperger, 1995; White et al., 2004), tall-stature wheat cultivars (Ogg and Seefeldt, 1999; Yenish and Young, 2004), increased wheat seeding rates (Kappler et al., 2002), incorporation of crop residue (Anderson, 1993a), postharvest burning (Young et al., 1990), and fertility management (Mesbah and Miller, 1999).

No herbicide options are available for selective control of jointed goatgrass in conventional winter wheat cultivars, although propoxycarbazone may provide some suppression of the weed (Fandrich et al., 2001; Geier et al., 2001). The commercial introduction of imazamox-resistant (IR) winter wheat cultivars has allowed the use of imazamox herbicide for selective control of jointed goatgrass, with minimal risk of crop injury (Ball et al., 1999; Frihauf et al., 2005; Pester et al., 2001).

The introduction of IR technology in winter wheat does not come without risk. Wheat $\times$ jointed goatgrass hybrids have been commonly found in winter wheat growing regions, and subsequent backcrossing to jointed goatgrass could result in a jointed goatgrass population that carries the IR trait (Gandhi et al., 2006; Morrison et al., 2002; Wang et al., 2001; Zemetra et al., 1998). Indeed, introgression of the IR trait in to jointed goatgrass has been confirmed under laboratory (Perez-Jones et al., 2006) and field (Seefeldt et al., 1998; Hanson et al., 2005) conditions. Hanson et al. (2005) estimate that the risk of introgression is likely equal to the risk of spontaneous mutation conferring imazamox resistance in the species. Additionally, Gaines et al. (2007) demonstrated the potential for movement of the IR trait into adjacent, conventional cultivars.

Based on results of a simulation analysis, Hanson et al. (2002) suggested that IR wheat should be rotated with fallow and/or crops other than IR winter wheat. Utilization of tillage in fallow years in the simulation slowed the rate of increase of IR jointed goatgrass biotypes, but did not slow the appearance of the trait when compared to a winter wheat-fallow rotation with no tillage.

The objectives of this study were to (i) compare use patterns of IR technology in winter wheat with respect to jointed goatgrass density and wheat grain contamination over three crop years in a winter wheat fallow system, and (ii) monitor jointed goatgrass and jointed goatgrass $x$ wheat hybrid populations for resistance to imazamox.

\section{MATERIALS AND METHODS}

The study was initiated near Lingle, WY $\left(42^{\circ} 05^{\prime} 16^{\prime} \mathrm{N}\right.$, $104^{\circ} 22^{\prime} 45^{\prime} \mathrm{W}$ ) in fall 2000 with the planting of winter wheat into a farmer's field with a heavy jointed goatgrass infestation (hereafter referred to as the East location). Wheat was sown on 28 Sept. 2000 at a rate of $78 \mathrm{~kg}$ seed $\mathrm{ha}^{-1}$ and a biannual rotation of winter wheat-fallow was then utilized for the duration of the study. In the fall of 2001, a second trial was planted to winter wheat in the same field in an adjacent strip to the west of the first site (hereafter referred to as the West location). This staggered initiation in adjacent fields allowed for the presence of both phases of the rotation (wheat following fallow, and fallow following wheat) to appear in each year of the study to minimize the environmental impact due to annual variation. The East and West locations were alternately planted to winter wheat or summer fallowed in subsequent years for a total of three wheat crop years at each site (Fig. 1). Wheat was sown at a rate of $67 \mathrm{~kg}$ seed ha $\mathrm{h}^{-1}$ in all years except 2000, and sowing dates ranged from 2 September to 10 September for all years except the initiation of the study in 2000. Nitrogen and phosphorus were applied before planting based on soil test results.

All data were collected in the spring or summer when wheat was present in the rotation. Data for the East location were first collected in 2001, and data for the West location were first collected in 2002. As 2001 and 2002 represent the first data collection and harvest for the East and West locations, respectively, these 2 yr will be referred to as the first crop year herewith (Fig. 1). Likewise 2003 and 2004 will be referred to as the second crop year; and 2005 and 2006 will be referred to as the third crop year. The study was concluded with the harvest of the wheat crop at the West location in the summer of 2006.

In the first crop year at each site, an IR wheat treatment was compared to a standard wheat treatment (STD) in a randomized complete block design (RCBD) with four replications. The IR treatment was planted to the IR cultivar Above each autumn following the fallow period and treated with imazamox in the spring at a rate of $36 \mathrm{~g}$ a.i. ha ${ }^{-1}$ plus $0.25 \%$ $\mathrm{v} / \mathrm{v}$ nonionic surfactant plus $1 \% \mathrm{v} / \mathrm{v}$ aqueous nitrogen $(28-0-0)$. All herbicide treatments were applied with a $\mathrm{CO}_{2}-$ pressurized knapsack sprayer delivering $225 \mathrm{~L} \mathrm{ha}^{-1}$ at $276 \mathrm{kPa}$. The STD treatment was planted to the cultivar Buckskin following the fallow period, and treated with bromoxynil (3,5-dibromo-4hydroxybenzonitrile) plus MCPA (4-chloro-o-tolyloxyacetic acid) in the spring at rates of 420 plus $420 \mathrm{~g}$ ai ha ${ }^{-1}$, respectively. No control of jointed goatgrass was expected from the herbicide application in the STD treatment, but it provided excellent control of Russian thistle (Salsola tragus L.) and flixweed [Descurainia sophia (L.) Webb. ex Prantl], the two dominant broadleaf weeds at the experimental sites. Imazamox provided similar control of these weeds in the IR treatment.

In the second crop year for each location, the initial plots were split into split-plots with either the IR or STD treatment applied within each whole plot. This process was repeated in the third crop year to establish split-split-plot treatments (Fig. 1). At the conclusion of the study, all possible combinations of the IR and STD treatments within a winter wheat-fallow rotation were applied at each site.

Jointed goatgrass tiller density data were collected each spring in the winter wheat crop by counting the number of reproductive tillers in four randomly placed $0.25-\mathrm{m}^{2}$ quadrats per split-split-plot $(7.3$ by $9.1 \mathrm{~m})$. Before harvest each year, the entire study area was searched for jointed goatgrass $\times$ wheat hybrids. Hybrid spikes were collected and brought back to the laboratory for viability testing. Hybrid spikes were stored in an unheated outdoor storage shed for 20 wk before germination tests. Jointed goatgrass seed heads were located and collected along a transect in each plot before harvest each year. To screen surviving jointed goatgrass plants for resistance to imazamox, spikelets collected from each plot were planted into 
East

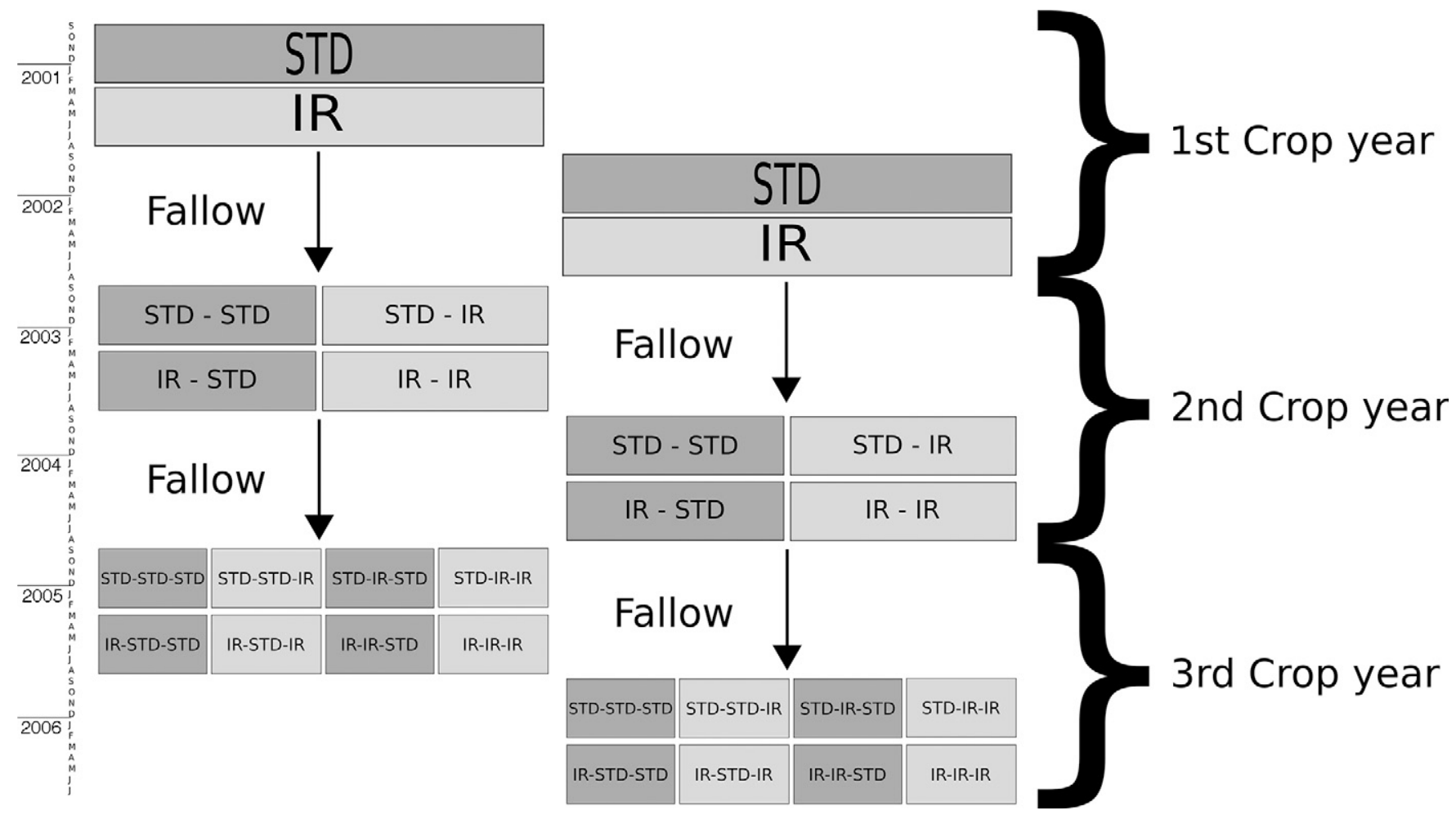

Figure 1. Nonrandomized example arrangement of treatments for one replicate through time. Abbreviations: STD, standard treatment of 'Buckskin' treated with bromoxynil plus MCPA; IR, imazamox-resistant treatment of 'Above' treated with imazamox.

pots in the greenhouse and treated with imazamox at $36 \mathrm{~g}$ ai $\mathrm{ha}^{-1}$ plus $0.25 \% \mathrm{v} / \mathrm{v}$ nonionic surfactant plus $1 \% \mathrm{v} / \mathrm{v}$ aqueous nitrogen (28-0-0). Treatments were applied in a spray chamber delivering $225 \mathrm{~L} \mathrm{ha}^{-1}$ at $276 \mathrm{kPa}$. A known susceptible jointed goatgrass population from Washington was also treated alongside the jointed goatgrass collected from the study area. Any plants surviving the imazamox application were treated a second time with the same rate of imazamox $21 \mathrm{~d}$ following the first application. A single plant surviving the second application in 2006 was transplanted, vernalized, and allowed to produce seed for further testing.

Wheat yield was collected each summer by harvesting two passes from each plot with a small plot grain harvester (approximately $24 \mathrm{~m}^{2}$ ). Two grain samples were collected from the harvester in each plot to determine percent dockage. Grain samples were taken back to the laboratory and a 100-g subsample was collected. Jointed goatgrass spikelets were removed from the sample and weighed to determine jointed goatgrass dockage on a per weight basis. The entire plot area was harvested following sample collection with the small plot harvester to ensure uniform distribution of straw, chaff, and weed seeds.

Data from each year at each site were analyzed separately using ANOVA due to a crop year by location interaction. Experimental design for data collected in the first crop year was a RCBD with four replications, with block and treatment considered fixed effects. Since treatments applied in the second crop year were applied to plots that had also received treatments the previous crop year (Fig. 1), treatment effects for crop year 2 were considered nested within treatment effects from the first crop year (Table 1). The experimental design for data collected in the second crop year was a split-plot factorial RCBD with four replications. The main plot factor was the treatment applied in the first crop year, and the split-plot factor was the treatment applied in the second crop year. Analysis of data from the second crop year, then, consisted of fixed effects of Block, Year 1 treatment, Year 2 treatment, and the nested effect of Year 2 within Year 1 . The Block $\times$ Year 1 interaction was considered random and was used as an error term in the model. Likewise, analysis of data from the third crop year considered Year 3 treatment effects as nested within Year 2. Experimental design for data collected in the third crop year was therefore a splitsplit-plot factorial RCBD with four replications; the main plot factor was the treatment applied in the first crop year, the splitplot factor was the treatment applied in the second crop year, and the split-split-plot factor was the treatment applied in the third crop year. The ANOVA for the split-split plot design for data collected in the third crop year is similar to that described by Steel and Torrie (1980). The MIXED procedure in SAS was used for all analysis using the default restricted maximum likelihood estimation method.

\section{RESULTS \\ West Location}

There were significant treatment effects $(P=0.05)$ in the first crop year for all variables (Table 1). The IR treatment resulted in reduced jointed goatgrass tiller density and jointed goatgrass contamination of grain (dockage), and increased wheat yield compared to the STD treatment. Excellent control of jointed goatgrass was achieved in the IR treatment, resulting in less than 1 jointed goatgrass 
tiller $\mathrm{m}^{-2}$ compared to 22 tillers $\mathrm{m}^{-2}$ in the STD treatment (Table 2). The excellent jointed goatgrass control resulted in greater quantity and quality wheat. Wheat yield in the STD treatment was 20\% less than that observed in the IR treatment (1400 and $1740 \mathrm{~kg} \mathrm{ha}^{-1}$, respectively), and grain dockage for the STD treatment was $32 \mathrm{~g} \mathrm{~kg}^{-1}$ of wheat yield compared to $4 \mathrm{~g} \mathrm{~kg}^{-1}$ in the IR treatment.

The high efficacy of the IR treatment observed in the first crop year was still noticeable in the second crop year, as evidenced by significance of the Year 2 within Year 1 treatment effects for jointed goatgrass tiller density, and a significant effect of Year 1 treatments for dockage (Table 1). On average, jointed goatgrass tiller density was less in the second crop year compared to the first crop year (Table 2). This difference is attributed to natural variation in weed density due to climatic conditions such as temperature and precipitation that influence jointed goatgrass emergence. The greatest jointed goatgrass density was observed where the STD treatment was applied for two consecutive crop years (6 tillers $\mathrm{m}^{-2}$ ), and this density was significantly greater than plots receiving the IR treatment in either year (less than 3 tillers $\mathrm{m}^{-2}$ ) including those that received the STD treatment in Year 2. With respect to dockage, treatment effects from the first crop year were significant $(P<0.05)$. When averaged over treatments applied in the second crop year, treatments that received the IR treatment in the first crop year had 50\% less jointed goatgrass contamination than plots receiving the STD treatment in the first year (4 and 2 $\mathrm{g} \mathrm{kg}^{-1}$, respectively).

Wheat yields were different between the two treatments in the second crop year, although the difference did not relate to jointed goatgrass density. At the initiation of this research, the cultivar Above was sown because it was the best adapted IR cultivar for the High Plains winter wheat growing region. However, Above is not as well adapted to southeast Wyoming as Buckskin. Under the low jointed goatgrass pressure observed in the second crop year, Buckskin out-yielded Above by 20\% (1560 and $1290 \mathrm{~kg}$ $\mathrm{ha}^{-1}$, respectively), even though jointed goatgrass density was greater in the STD treatment.

Jointed goatgrass density continued to decline over the course of the study at this location. In the third crop year, average jointed goatgrass tiller density was less than $1 \mathrm{~m}^{-2}$ for all treatments, although treatment effects from Year 3 were statistically significant $(P<0.05$; Table 1$)$. No jointed goatgrass tillers or dockage were recorded in plots receiving the IR treatment in the third crop year regardless of previous treatment. The STD treatment resulted in a jointed goatgrass tiller density of $0.5 \mathrm{~m}^{-2}$ (Table 2) and jointed goatgrass contamination of $0.2 \mathrm{~g} \mathrm{~kg}^{-1}$ of total wheat yield. Although jointed goatgrass densities were lower than those observed in the second crop year, the IR treatment resulted in greater wheat yields compared to the STD treatment. This difference is again explained by differences between cultivars rather than differences in weed control. In the third crop year, a heavy infestation of wheat-stem sawfly (Cephus cinctus Norton) demonstrated a preference for Buckskin. It is unclear why this pest preferentially attacked Buckskin, but the yield differences were largely attributed to broken stems in the STD treatment.

\section{East Location}

Significant treatment effects were observed with respect to jointed goatgrass tiller density, grain dockage, and wheat yield in the first year of the study (Table 1). Jointed goatgrass tiller densities were initially higher at this location (34 tillers $\mathrm{m}^{-2}$ ) compared to the West location (22 tillers 
Table 2. Jointed goatgrass density as influenced by imazamox-resistant (IR) or standard (STD) production systems at two locations near Lingle, WY, 2000 through 2006.

\begin{tabular}{|c|c|c|c|}
\hline \multirow{2}{*}{$\begin{array}{l}\text { Crop } \\
\text { year }\end{array}$} & \multirow{2}{*}{ Treatment } & \multicolumn{2}{|c|}{ Jointed goatgrass density } \\
\hline & & West location & East location \\
\hline & & \multicolumn{2}{|c|}{ — tillers $\mathrm{m}^{-2}$} \\
\hline \multirow[t]{2}{*}{1} & IR & $0.03 \mathrm{a}^{\dagger}$ & $3 a$ \\
\hline & STD & $22 \mathrm{~b}$ & $34 b$ \\
\hline \multirow[t]{6}{*}{2} & IR in Year 2 & $N S^{\ddagger}$ & $1 a$ \\
\hline & STD in Year 2 & NS & $18 \mathrm{~b}$ \\
\hline & IR-IR & $0.3 a$ & $0.5^{\S}$ \\
\hline & IR-STD & $1 a b$ & 18 \\
\hline & STD-IR & $2 b$ & 2 \\
\hline & STD-STD & $6 c$ & 17 \\
\hline \multirow[t]{12}{*}{3} & IR in Year 2 & NS & $14 a$ \\
\hline & STD in Year 2 & NS & $27 b$ \\
\hline & IR in Year 3 & $\mathrm{Oa}$ & NS \\
\hline & STD in Year 3 & $0.5 b$ & NS \\
\hline & IR-IR-IR & $0 \S$ & $17 \S$ \\
\hline & IR-IR-STD & 0.3 & 9 \\
\hline & IR-STD-IR & 0 & 28 \\
\hline & IR-STD-STD & 0.9 & 28 \\
\hline & STD-IR-IR & 0 & 6 \\
\hline & STD-IR-STD & 0.1 & 22 \\
\hline & STD-STD-IR & 0 & 13 \\
\hline & STD-STD-STD & 0.6 & 36 \\
\hline
\end{tabular}

${ }^{\dagger}$ Means within a crop year followed by the same letter are not significantly different at the 0.05 probability level.

‡NS, not significant (0.05).

§Two-year interaction effects at the East location and 3-yr interaction effects at both locations are not statistically significant, but simple effects means are provided for the reader's information.

$\mathrm{m}^{-2}$ ). The IR treatment provided effective control in the first crop year, resulting in a $91 \%$ reduction in jointed goatgrass tiller density compared to the STD treatment (Table 2). Dockage followed a similar trend, as the IR treatment contained only $5 \mathrm{~g}$ of jointed goatgrass spikelets per kilogram of clean grain yield compared to $76 \mathrm{~g} \mathrm{~kg}^{-1}$ in the STD treatment. Even under the intense jointed goatgrass competition in the first crop year at this location, the better adapted Buckskin was able to yield greater than Above (702 and $549 \mathrm{~kg} \mathrm{ha}^{-1}$, respectively). Wheat yields at this location were low due to unseasonably cold and dry conditions following establishment in the fall of 2000.

Nearly identical results were observed in the second crop year, with the IR treatment resulting in 94 and $71 \%$ reductions in jointed goatgrass tiller density and dockage, respectively, compared to the STD treatment when averaged over treatments applied in Year 1 (Table 2). The IR treatment resulted in 1 jointed goatgrass tiller $\mathrm{m}^{-2}$ and grain dockage of $18 \mathrm{~g} \mathrm{~kg}^{-1}$ compared to 18 tillers $\mathrm{m}^{-2}$ and dockage of $61 \mathrm{~g} \mathrm{~kg}^{-1}$ in the STD treatment. A significant nested effect of Year 2 within Year 1 was observed with respect to wheat yield in the second crop year (Table 1) with wheat yields of 997, 1407, 1029, and $1189 \mathrm{~kg} \mathrm{ha}^{-1}$ for the IR-IR, IR-STD, STD-IR, and STD-STD treatments, respectively. Tiller density data did not show a nested effect of years, as the densities were clearly a result of the treatments applied in crop year 2. Although tiller densities were similar, the jointed goatgrass in the STD followed by STD treatment appeared visually to be more competitive (taller in stature, more spikelets) compared to jointed goatgrass in the IR followed by STD (data not shown). Less competitive jointed goatgrass plants resulting from IR treatment applied the first year combined with the better adapted cultivar in the STD treatment may explain the interaction effect in the second crop year with respect to wheat yield.

Activity of imazamox was dramatically reduced in the third crop year compared to previous years due to very dry early spring conditions. A marginally significant $(P=0.0516)$ 3 -yr interaction was observed with respect to jointed goatgrass tiller density, but the most notable effect in the third crop year was a result of treatments applied in the second crop year (Table 1). Where IR treatments were applied in the second crop year, a $48 \%$ reduction in jointed goatgrass tiller density (Table 2 ) and $42 \%$ reduction in dockage (15 compared to $27 \mathrm{~g} \mathrm{~kg}^{-1}$ in the STD treatment) could still be observed in the third crop year when averaged over third year treatments. No treatment effects were observed with respect to wheat yield in the third crop year.

\section{Hybrid Collection and Viability}

Each year, the experimental area was searched for jointed goatgrass $\times$ wheat hybrids. Hybrids were found and collected in 4 of the $6 \mathrm{yr}$ of study. A total of $0,0,3,43,27$, and 22 hybrid spikes were collected from 2001 to 2006, respectively. No viable seed was produced by any hybrid through the course of this study. Given the relatively low numbers of hybrid plants collected, this result is not surprising (Wang et al., 2001).

\section{Resistance Screening}

Each year, jointed goatgrass spikes were collected along transects in each plot and screened for resistance to imazamox in the greenhouse. No jointed goatgrass plants survived greenhouse imazamox treatments from 2001 through 2005. In 2006, however, a single jointed goatgrass plant originally collected from a plot that had received IR treatments in all three crop years survived two applications of imazamox at $36 \mathrm{~g} \mathrm{ha}^{-1}$. The surviving plant was transplanted, vernalized, and allowed to grow to maturity under greenhouse conditions. Although the plant produced a high number of tillers and spikelets following vernalization, no seed was produced.

\section{DISCUSSION}

As expected, the IR treatment reduced jointed goatgrass tiller density and grain dockage compared to the 
STD treatment in most years. The results presented here indicate that high densities of jointed goatgrass may be reduced in a single year, thereby reducing the need to use the IR treatment in consecutive crop years. Perhaps most importantly, effects of the IR treatments were evident at both the East and West location in STD treatments the following cropping year. This result may be important for management of IR wheat, as imazamox is an acetolactose synthase (ALS)-inhibiting herbicide, and ALS-inhibiting herbicides are prone to rapid development of resistant weed biotypes (Norris et al., 2003). Although no IR jointed goatgrass biotypes have yet been reported, a proactive approach to minimizing this risk may be prudent. Hanson et al. (2002) recommend rotation of IR wheat with fallow and/or crops other than IR wheat to slow this rate of resistance development. This recommendation could be interpreted as a rotation of IR and non-IR cultivars in a wheat-fallow rotation. This would reduce the selection pressure for an IR jointed goatgrass population compared to use of IR technology every crop year. This approach is especially appealing since the benefits of IR technology can still be observed in conventional wheat cultivars grown in subsequent years. If nonselective herbicides or tillage are utilized in fallow years, then the development of a resistant population could be delayed further.

The reduction of jointed goatgrass in subsequent years is especially meaningful for regions where IR cultivars may not be well adapted. As illustrated in this research, there may be a benefit to rotating the IR treatment with a better adapted conventional cultivar. The jointed goatgrass density may be reduced by the IR treatment to the point where a more competitive cultivar may provide excellent yields in a subsequent crop year. Above was the IR cultivar used in this research because it was the best adapted cultivar at the initiation of this study. Since that time, better adapted IR cultivars with higher yield potential in southeast Wyoming have become commercially available (J. Krall, personal communication, 2008).

It is unclear whether the lack of seed produced by a jointed goatgrass plant treated with imazamox in the greenhouse was due to imazamox treatment. Baker et al. (1999) report that imazapic (2-[(RS)-4-isopropyl-4-methyl-5-oxo-2-imidazolin-2-yl]-5-methylnicotinic acid) and imazaquin (2-[(RS)-4-isopropyl-4-methyl-5-oxo2-imidazolin-2-yl]quinoline-3-carboxylic acid), ALSinhibiting herbicides similar to imazamox, can suppress seed-head development when applied at sublethal rates. However, Deeds et al. (2006) found that if wheat treated with imazamox at sublethal rates was able to produce seed, viability of the seed was not affected. The lack of viable hybrid seed or resistant jointed goatgrass plants observed in this research should not be interpreted as an indication of the risk level associated with use of IR technology. The scale of this research (both temporally and spatially) was insufficient to adequately determine the hybridization rate or percentage of viable seed produced by hybrids. It has been predicted that after $6 \mathrm{yr}$ in a wheat-fallow rotation where IR technology was used every crop year, the proportion of resistant jointed goatgrass biotypes would be around $1 \%$ or less (Hanson et al., 2002). It is possible that the sampling scheme used in this research was insufficient to detect such a low proportion of resistant seed.

In a winter wheat-fallow rotation, it is likely that use of IR technology will allow effective management of jointed goatgrass populations, and reduce economic losses due to grain dockage. Use of the technology every other crop year, or two out of every three crop years under conditions of high goatgrass densities, will reduce the selection pressure for resistant jointed goatgrass populations compared to continuous use of the trait, while still providing management benefits in subsequent years. Other management practices, such as competitive conventional cultivars and nonselective herbicides and tillage in fallow years, should also be used in the system to reduce the selection pressure for resistant weed biotypes.

\section{Acknowledgments}

This research was funded by the National Jointed Goatgrass Research Program.

\section{References}

Anderson, R. 1993a. Crop residue reduces jointed goatgrass (Aegilops cylindrica) seedling growth. Weed Technol. 7:717-722.

Anderson, R. 1993b. Jointed goatgrass (Aegilops cylindrica) ecology and interference in winter wheat. Weed Sci. 41:388-393.

Ball, D., B. Klepper, and D. Rydrych. 1995. Comparative aboveground development rates for several annual grass weeds and cereal grains. Weed Sci. 43:410-416.

Ball, D., F. Young, and A.J. Ogg. 1999. Selective control of jointed goatgrass (Aegilops cylindrica) with imazamox in herbicide-resistant wheat. Weed Technol. 13:77-82.

Baker, R.D., L.B. McCarty, D.L. Colvin, J.M. Higgins, J.S. Weinbrecht, and J.E. Moreno. 1999. Bahiagrass (Paspalum notatum) seedhead suppression following consecutive yearly applications of plant growth retardants. Weed Technol. 13:378-384.

Deeds, Z.A., K. Al-Khatib, D.E. Peterson, and P.W. Stahlman. 2006. Wheat response to simulated drift of glyphosate and imazamox applied at two growth stages. Weed Technol. 20:23-31.

Donald, W., and A.J. Ogg. 1991. Biology and control of jointed goatgrass (Aegilops cylindrica), a review. Weed Technol. 5:3-17.

Dotray, P., and F. Young. 1993. Characterization of root and shoot development of jointed goatgrass (Aegilops cylindrica). Weed Sci. 41:353-361.

Fandrich, L., S. McDonald, S. Nissen, P. Westra, and H. Santel. 2001. Absorption and fate of BAY MKH 6561 in jointed goatgrass and downy brome. Weed Sci. 49:717-722.

Fleming, G.F., F.L. Young, and A.G. Ogg, Jr. 1988. Competitive relationships among winter wheat (Triticum aestivum), jointed goatgrass (Aegilops cylindrica), and downy brome (Bromus tectorum). Weed Sci. 36:479-486.

Frihauf, J.C., S.D. Miller, and C.M. Alford. 2005. Imazamox rates, timings, and adjuvants affect imidazolinone-tolerant winter wheat cultivars. Weed Technol. 19:599-607. 
Gaines, T., C. Preston, P. Byrne, W.B. Henry, and P. Westra. 2007. Adventitious presence of herbicide resistant wheat in certified and farm-saved seed lots. Crop Sci. 47:751-756.

Gandhi, H., R. Zemetra, O. Riera-Lizarazu, M. Vales, C. Mallory-Smith, and C. Watson. 2006. Hybridization between wheat and jointed goatgrass (Aegilops cylindrica) under field conditions. Weed Sci. 54:1073-1079.

Geier, P., P. Stahlman, and J. Hargett. 2001. Dose responses of weeds and winter wheat to MKH 6561. Weed Sci. 49:788-791.

Hanson, B., C. Mallory-Smith, W. Price, B. Shafii, D. Thill, and R. Zemetra. 2005. Interspecific hybridization: Potential for movement of herbicide resistance from wheat to jointed goatgrass (Aegilops cylindrica). Weed Technol. 19:674-682.

Hanson, D., D. Ball, and C. Mallory-Smith. 2002. Herbicide resistance in jointed goatgrass (Aegilops cylindrica): Simulated responses to agronomic practices. Weed Technol. 16:156-163.

Kappler, B., D. Lyon, P. Stahlman, S. Miller, and K. Eskridge. 2002. Wheat plant density influences jointed goatgrass (Aegilops cylindrica) competitiveness. Weed Technol. 16:102-108.

Lyon, D., and D. Baltensperger. 1995. Cropping systems control winter annual grass weeds in winter wheat. J. Prod. Agric. 8:535-539.

Lyon, D., J. Smith, and D. Jones. 1994. Sampling wheat (Triticum aestivum) at the elevator for jointed goatgrass (Aegilops cylindrica). Weed Technol. 8:64-68.

Mesbah, A., and S. Miller. 1999. Fertilizer placement affects jointed goatgrass (Aegilops cylindrica) competition in winter wheat (Triticum aestivum). Weed Technol. 13:374-377.

Morrison, L., O. Riera-Lizarazu, L. Cremieux, and C. MallorySmith. 2002. Jointed goatgrass (Aegilops cylindrica Host) $\times$ wheat (Triticum aestivum L.) hybrids: Hybridization dynamics in Oregon wheat fields. Crop Sci. 42:1863-1872.

Norris, R.F., E.P. Caswell-Chen, and M. Kogan. 2003. Resistance, resurgence, and replacement. p. 328-329. In Concepts in integrated pest management. Prentice Hall, Upper Saddle River, NJ.

Ogg, A.J., and S. Seefeldt. 1999. Characterizing traits that enhance the competitiveness of winter wheat (Triticum aestivum) against jointed goatgrass (Aegilops cylindrica). Weed Sci. 47:74-80.

Perez-Jones, A., C.A. Mallory-Smith, J.L. Hansen, and R.S. Zemetra. 2006. Introgression of an imidazolinone-resistance gene from winter wheat (Triticum aestivum L.) into jointed goatgrass (Aegilops cylindrica Host). Theor. Appl. Genet. 114:177-186.

Pester, T., S. Nissen, and P. Westra. 2001. Absorption, translocation, and metabolism of imazamox in jointed goatgrass and feral rye. Weed Sci. 49:607-612.

Seefeldt, S., R. Zemetra, F. Young, and S. Jones. 1998. Production of herbicide-resistant jointed goatgrass (Aegilops cylindrica) $\times$ wheat (Triticum aestivum) hybrids in the field by natural hybridization. Weed Sci. 46:632-634.

Steel, R.G., and J.H. Torrie. 1980. Principles and procedures of statistics. 2nd ed. McGraw Hill, New York.

Wang, Z., R. Zemetra, J. Hansen, and C. Mallory-Smith. 2001. The fertility of wheat $\times$ jointed goatgrass hybrid and its backcross progenies. Weed Sci. 49:340-345.

White, A., P. Stahlman, and F. Northam. 2004. Impact of integrated management systems on jointed goatgrass (Aegilops cylindrica) populations. Weed Sci. 52:1010-1017.

Yenish, J., and F. Young. 2004. Winter wheat competition against jointed goatgrass (Aegilops cylindrica) as influenced by wheat plant height, seeding rate, and seed size. Weed Sci. 52:996-1001.

Young, F., A.J. Ogg, and P. Dotray. 1990. Effect of postharvest field burning on jointed goatgrass (Aegilops cylindrica) germination. Weed Technol. 4:123-127.

Zemetra, R., J. Hansen, and C. Mallory-Smith. 1998. Potential for gene transfer between wheat (Triticum aestivum) and jointed goatgrass (Aegilops cylindrica). Weed Sci. 46:313-317. 